\title{
Spatially Explicit Life Cycle Analysis of Cellulosic Ethanol Production Scenarios in Southwestern Michigan
}

\author{
Keith R. Cronin ${ }^{1}$ - Troy M. Runge ${ }^{1,2} \cdot$ Xuesong Zhang ${ }^{3,4} \cdot$ R. César Izaurralde ${ }^{3,4}$. \\ Douglas J. Reinemann ${ }^{2}$ • Julie C. Sinistore ${ }^{5}$
}

Published online: 13 July 2016

(C) The Author(s) 2016. This article is published with open access at Springerlink.com

\begin{abstract}
Modeling the life cycle of fuel pathways for cellulosic ethanol (CE) can help identify logistical barriers and anticipated impacts for the emerging commercial CE industry. Such models contain high amounts of variability, primarily due to the varying nature of agricultural production but also because of limitations in the availability of data at the local scale, resulting in the typical practice of using average values. In this study, 12 spatially explicit, cradle-to-refinery gate $\mathrm{CE}$ pathways were developed that vary by feedstock (corn stover, switchgrass, and Miscanthus), nitrogen application rate (higher, lower), pretreatment method (ammonia fiber expansion [AFEX], dilute acid), and co-product treatment method (mass allocation, sub-division), in which feedstock production was modeled at the watershed scale over a nine-county area in Southwestern Michigan. When comparing feedstocks, the model showed that corn stover yielded higher global warming potential (GWP), acidification potential (AP), and
\end{abstract}

Electronic supplementary material The online version of this article (doi:10.1007/s12155-016-9774-7) contains supplementary material, which is available to authorized users.

Troy M. Runge

trunge@wisc.edu

1 DOE Great Lakes Bioenergy Research Center, University of Wisconsin-Madison, Madison, WI, USA

2 Biological Systems Engineering Department, University of Wisconsin-Madison, Madison, WI, USA

3 DOE Great Lakes Bioenergy Research Center, University of Maryland-College Park, College Park, MD, USA

4 Joint Global Change Research Institute of Pacific Northwest National Laboratory and the University of Maryland-College Park, College Park, MD, USA

5 WSP $\mid$ Parsons Brinckerhoff, New York, NY, USA eutrophication potential (EP) than the perennial feedstocks of switchgrass and Miscanthus, on an average per area basis. Full life cycle results per MJ of produced ethanol demonstrated more mixed results, with corn stover-derived CE scenarios that use sub-division as a co-product treatment method yielding similarly favorable outcomes as switchgrass- and Miscanthus-derived CE scenarios. Variability was found to be greater between feedstocks than watersheds. Additionally, scenarios using dilute acid pretreatment had more favorable results than those using AFEX pretreatment.

Keywords Life cycle analysis $\cdot$ Energy crops $\cdot$ Spatially explicit · Eutrophication potential $\cdot$ Global warming potential . Bioenergy

\section{Introduction}

The life cycle production of second-generation cellulosic ethanol (CE) and its environmental impacts are less studied and more uncertain than that of first-generation corn grain ethanol. Developing and testing potential scenarios for CE fuel pathways is one method for investigating this uncertainty and exploring sensitive life cycle parameters and assumptions to anticipate the volume increase of $\mathrm{CE}$ in the portfolio of biofuels consumed in the USA. Currently, a commercial CE industry is emerging in the USA and Europe; thus, testing various scenarios can help distinguish more favorable fuel pathway choices and inform the range of impacts that might be expected of such an industry.

The selection of a cellulosic feedstock from which the eventual ethanol will be derived is a major source of variability among CE pathways. Feedstock options include agricultural and forestry residues as well as dedicated bioenergy crops [1]. Factors such as the resource inputs required to 
harvest a sustainable yield, environmental limitations on cultivation and gathering the biomass, and logistical considerations such as storage and transportation requirements are influencing the selection of a feedstock. Beyond the feedstock production phase of the life cycle, pretreatment of the feedstock is required to make cellulose and hemicellulose available for enzymatic hydrolysis, and a variety of pretreatment methods have been developed [2,3]. The efficiency of a pretreatment method in yielding sugars for fermentation, as well as the material and energy input needed in the process, can alter the comparative advantage of one feedstock over another and introduces additional uncertainty. Understanding these life cycle processes and their impacts is critical because of their significant effect on the sustainability of a particular pathway [4].

Contributing to the variability in dedicated feedstock production is the unpredictable nature of agricultural production, where spatially explicit characteristics such as soil conditions and weather can affect LCA outcomes for the same feedstock grown in different locations [5]. Potting and Hauschild [6] identified three tiers of spatial differentiation for LCA modeling: site generic (global-scale data), site dependent (regionalscale data), and site specific (local-scale data). Using the most locally precise level of data available will result in a more precise analysis of cellulosic ethanol production in a certain area, though local political units such as states or counties may not provide the best geographical system boundaries for landoriented agricultural production. Past studies have identified useful "spatial units" such as watersheds for incorporating appropriately scaled data into LCA [7, 8]. Choosing an appropriate scale in an LCA must be weighed against the effort needed to collect increasingly minute data, though using site-specific data, where available, to create spatially explicit scenarios for CE pathways through the ethanol refinery phase yields more precise comparisons of pathways than if sitedependent data is used or if life cycle processes are studied in isolation.

The objective of this study was to contrast feedstocks, nitrogen intensity, and pretreatment methods while incorporating site-specific LCA data to generate a spatially explicit analysis of CE production and identify favorable fuel pathways. Six feedstock production scenarios were developed based on watershed-level feedstock production data for corn stover, switchgrass, and Miscanthus grown under higher and lower nitrogen input conditions in Southwestern Michigan. The analysis has then extended our analysis to the biorefinery, with the application of two contrasting pretreatment options - ammonia fiber expansion (AFEX) and dilute acid (DA) - as well as two different co-product allocation methods for corn stover production, yielding $16 \mathrm{CE}$ production scenarios that were compared using four impact category metrics: net energy ratio (NER), global warming potential (GWP), acidification potential (AP), and eutrophication potential (EP).

\section{Methodology}

Methods used in conducting this cradle-to-gate LCA of CE production followed guidelines established in the ISO standards concerning LCA $[9,10]$. A consequential approach was used while incorporating some elements of attribution, beginning with an assumption that a pulse of demand in the market for cellulosic feedstocks would spur construction of a CE plant in Southwestern Michigan and prime land currently used to produce field crops, specifically corn and soybeans, would be converted to bioenergy feedstock production. LCA models for 16 ethanol production scenarios were developed, presented in Table 1, that vary by feedstock (corn stover, switchgrass, Miscanthus), co-product treatment method (mass allocation, sub-division), nitrogen application rate (higher nitrogen, lower nitrogen), and pretreatment method (AFEX, DA). GaBi product sustainability software, version 5.0, was used to model the scenarios and to test the sensitivity of environmental impact category metrics to variability occurring in spatial parameters [11].

The functional unit in this study was $1 \mathrm{MJ}$ of ethanol fuel (low heating value, LHV) produced from cellulosic feedstocks. The analysis was restricted to a nine-county regionally intensive modeling Area (RIMA) in southwestern Michigan made up of 39 watersheds, identified using their unique hydrologic unit code (HUC). One annual average year of agricultural and refinery production was modeled with an assumed 12-year life span for the switchgrass and Miscanthus crops, which included 2 years of establishment and 10 years of an annual harvest.

The modeled CE production system consisted of two portions: feedstock production and ethanol refining. The feedstock production portion included cultivation processes used throughout a growing season, and the ethanol refining portion included processes required to convert raw cellulosic feedstock to ethanol. Material and energy inputs for each phase and their upstream impacts were included in the system boundary. Bioenergy feedstock was the intermediate output of the feedstock production portion, with a transportation process accounting for impacts from transporting feedstock to the biorefinery. Ethanol resulting from the refining portion was the main output of the modeled system, with secondary outputs of electricity and treated water resulting from lignin combustion and wastewater treatment at the refinery. Figure 1 depicts the components included in the system.

Modeling of the feedstock production portion of the system was varied by the three bioenergy feedstock crops and by two nitrogen application rates. Switchgrass and Miscanthus are perennials and were assumed to be harvested annually following 2 years of establishment, while corn is planted and harvested annually. The model assumed that corn stover would be harvested from a corn-soybean rotation at a rate of $50 \%$ to 
Table 1 CE production scenarios

\begin{tabular}{llll}
\hline $\begin{array}{l}\text { Bioenergy } \\
\text { feedstock }\end{array}$ & $\begin{array}{l}\text { Nitrogen application } \\
\text { rate }\left(\mathrm{kg} \mathrm{N} \mathrm{ha}^{-1}\right)\end{array}$ & $\begin{array}{l}\text { Pretreatment } \\
\text { method }\end{array}$ & $\begin{array}{l}\text { Co-product } \\
\text { treatment method }\end{array}$ \\
\hline Corn stover & Higher 67.5 & $\begin{array}{l}\text { AFEX } \\
\text { DA }\end{array}$ & $\begin{array}{l}\text { Mass allocation } \\
\text { Mass allocation }\end{array}$ \\
& Lower 55 & AFEX & Mass allocation \\
Corn stover & Higher 67.5 & DA & Mass allocation \\
& & AFEX & Sub-division \\
& Lower 55 & DA & Sub-division \\
Switchgrass & Higher 90 & AFEX & Sub-division \\
& & DA & Sub-division \\
& Lower 60 & AFEX & NA \\
& & DA & NA \\
Mi s canthus & Higher 90 & AFEX & NA \\
& & DA & NA \\
& Lower 60 & AFEX & NA \\
& & DA & NA \\
& & AFEX & NA \\
\hline
\end{tabular}

Note that because corn is grown in rotation with soybeans, the $\mathrm{N}$ application rate in corn years is 135 and $110 \mathrm{~kg} \mathrm{~N} \mathrm{ha}^{-1}$ in the higher and lower $\mathrm{N}$ scenarios, respectively, so the annual average $\mathrm{N}$ input attributed to the corn crop is reduced by half

maintain soil fertility [12]. Modeled rates of agricultural input for fertilizers and pesticides are presented in Table 2, along with lower heating values for the respective crops. Production of each crop was modeled as a shift from a baseline production scenario to simulate land transitioning from a typical agricultural convention to one managed for bioenergy feedstock production. The baseline scenario was a corn-soybean rotation with a higher nitrogen application rate, chisel till, and no stover removal, representative of standard practices in the moderate range for environmental impacts.

The Environment Policy Integrated Climate (EPIC) model was used to generate output values for crop yield and soil emissions to air and water at $56 \mathrm{~m} \times 56 \mathrm{~m}$ resolution. Zhang et al. [13] detail the methodology and data sources used by the EPIC model, both of which have been well validated [14-17]. The model employs a plant growth submodel to project biomass yields, as well as climatic and environmental data to incorporate the effects of erosion, water inflow and outflow, nitrogen and phosphorus cycling, and emissions of greenhouse gases (GHGs). This data is applied in combination with spatially dependent parameters pertaining to climate, which were derived from the Daily Surface Weather and Climatological Summary (DayMet) and North American Regional Reanalysis (NARR); soils, derived from the U.S. Department of Agriculture Soil Survey Geographic (SSURGO) data; land use, derived from Crop Data Layer (CDL) images; and topography and hydrology, derived from the Shuttle Radar Topography Mission (SRTM) and the National Hydrography Dataset (NHD-plus). Model output values were then aggregated up to the scale of each of the 39 watersheds in the Michigan RIMA, and standard deviations were also reported with the watershed averages for investigation of spatial variability effects.

The EPIC model was run with 1986-2009 climate forcing parameters and a corn-soybean rotation to estimate the initial state of soils, including surface residue and soil organic carbon (SOC). Following this initial run, the same climate forcing parameters were implemented but for the corn-soybean, switchgrass, and Miscanthus cropping systems used in the analysis in order to derive productivity, GHGs, and environmental impacts for these systems. All crop parameters used in the EPIC model simulations were default parameters except
Fig. 1 Cellulosic ethanol production system

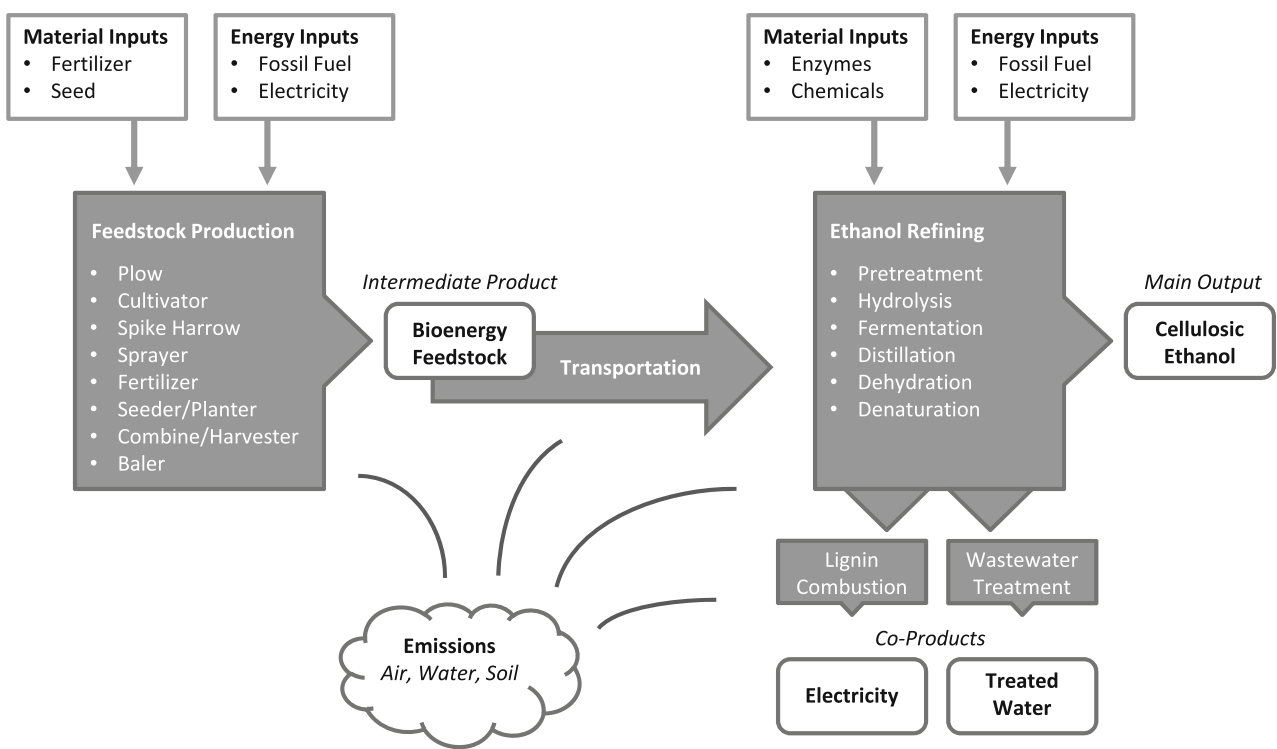


Table 2 Characteristics and inputs for corn stover, switchgrass, and Miscanthus

\begin{tabular}{|c|c|c|c|c|}
\hline & Baseline & Corn stover & Switchgrass & Miscanthus \\
\hline Features of feedstock production & $\begin{array}{l}\text { Biennial rotation of } \\
\text { corn and soybeans, } \\
\text { chisel tilled, } 0 \% \\
\text { stover harvest }\end{array}$ & $\begin{array}{l}\text { Biennial rotation of } \\
\text { corn and soybeans, } \\
\text { chisel tilled, } 50 \% \\
\text { stover harvest }\end{array}$ & $\begin{array}{l}\text { Perennial, 2-year } \\
\text { establishment } \\
\text { period, } 10 \text { years of } \\
\text { annual harvest }\end{array}$ & $\begin{array}{l}\text { Perennial, 2-year } \\
\text { establishment } \\
\text { period, } 10 \text { years of } \\
\text { annual harvest }\end{array}$ \\
\hline Nitrogen: higher rate $\left(\mathrm{kg} \mathrm{N} \mathrm{ha}^{-1}\right)$ & 135 & 135 & 90 & 90 \\
\hline Nitrogen: lower rate $\left(\mathrm{kg} \mathrm{N} \mathrm{ha}^{-1}\right)$ & NA & 110 & 60 & 60 \\
\hline Phosphorus $\left(\mathrm{kg} \mathrm{P} \mathrm{ha}^{-1}\right)$ & 24 & 24 & 0 & 0 \\
\hline Potassium (kg K ha $\left.{ }^{-1}\right)$ & 34 & 34 & 34 & 0 \\
\hline Lime ( $\mathrm{kg}$ lime $\left.\mathrm{ha}^{-1}\right)$ & & $\begin{array}{l}\text { Varied based on crop } \\
\text { requirements } \\
\text { and soil pH }\end{array}$ & & \\
\hline Pesticide input $\left(\mathrm{kg} \mathrm{AI} \mathrm{ha}^{-1}\right)$ & 1 & 1 & 0 & 0 \\
\hline LHV (MJ kg dry matter ${ }^{-1}$ ) & NA & 17.1 & 16.8 & 17.8 \\
\hline
\end{tabular}

for root-shoot ratios for switchgrass and Miscanthus which were based on field observations derived from literature [18, 19] and potential heat units which were derived from Zhang et al. [20]. Marginal lands were excluded from the production scenarios to focus on prime land with maximum potential for yield. Energy input and emissions resulting from soybean production were removed from the EPIC model output values in order to supply only environmental impacts for corn grain and corn stover production. Once the corn stover left the feedstock production portion of the system, two different coproduct treatment methods, mass allocation and sub-division, were applied in $\mathrm{GaBi}$ to all feedstock production inputs in order to generate results for impacts due only to corn stover. Of the more commonly used co-product treatment methods, mass allocation typically attributes the most environmental burden to stover while sub-division attributes the least [21-23]. The mass allocation factor for stover in this study was $33 \%$, and it was applied to production inputs as well as EPIC modeling data input. The sub-division allocation factor was $2 \%$ based on proportion of inputs due to collection of corn stover from the field and replacement of nutrients removed with the stover [21].

The modeled system boundary extended through the biorefinery, where the AFEX and DA pretreatment methods were selected as two prevailing technologies likely to be used for commercial scale CE production. Scientists and researchers affiliated with the Great Lakes Bioenergy Research Center (GLBRC) provided pretreatment data for the AFEX method [24, 25], as did Laser et al. [26], and data for the DA pretreatment was obtained from a 2011 study by the National Renewable Energy Laboratory (NREL) [27]. The 2011 NREL study also specified the inputs used for enzymatic hydrolysis and fermentation, wastewater treatment, distillation, dehydration, denaturation, and lignin combustion for electricity. The electricity co-product was assumed to displace electricity requirements at the refinery, with any excess displacing electricity from the grid.

The MyPower electricity sector model [28] supplied emission factors for electricity production specific to the state of Michigan, while the Greenhouse gases, Regulated Emissions, and Energy use in Transportation (GREET) model [29] supplied emission factors for transportation and process-heating fuels. The ethanol refinery was assumed to be located near the geographical center of the Michigan RIMA and calculated the average distance from any point in a circle with area equal to that of the RIMA to use as an average transportation distance from farm gate to refinery. Additional sources of data are available in Supplemental Table 1 and include the U.S. LCI dataset from NREL [30] and the EcoInvent and PE International Professional databases available in $\mathrm{GaBi}[11$, 31].

The environmental impact in each scenario was measured by four impact category metrics: net energy ratio (NER), global warming potential (GWP), acidification potential (AP), and eutrophication potential (EP). NER is reported in units of energy output divided by energy input (MJ output $\mathrm{MJ}_{\text {input }}{ }^{-1}$ ), while emissions contributing to GWP, AP, and EP are reported in units of carbon dioxide equivalents per energy output $(\mathrm{kg}$ $\mathrm{CO}_{2}$ eq MJ fuel ${ }^{-1}$ ), sulfur dioxide equivalents per energy output ( $\mathrm{g} \mathrm{SO}_{2}$ eq $\mathrm{MJ} \mathrm{fuel}^{-1}$ ), and phosphate equivalents per energy output $\left(\mathrm{g} \mathrm{PO}_{4}\right.$ eq $\left.\mathrm{MJ}_{\text {fuel }}{ }^{-1}\right)$, respectively. Feedstock production parameters from EPIC that were used in calculating these metrics include feedstock yield, release and uptake of carbon, nitrous oxide emissions, nitrogen loss, and phosphorus loss, with the EcoInvent and PE databases providing the parameters of diesel fuel, fertilizer input, seed, and associated 
upstream energy and materials to produce these inputs. Material and energy inputs for the transportation step and the ethanol refining portion of the system boundary were collected from data sources previously discussed. While emissions contributing to GWP included those from feedstock production, transportation of feedstock to the refinery, fermentation, combustion of lignin and biogas, and the carbon component of the final ethanol product, as well as impacts from direct land use change (LUC) as incorporated through the modeled shift from the baseline corn-soybean production scenario, indirect LUC (iLUC) impacts were not included in this metric. To date, there is no authoritative method for calculating iLUC impacts in bioenergy production and the topic continues to engender scientific debate [32]; thus, iLUC impacts were not considered in this study, though the authors acknowledge the limitation that this imposes on the analysis.

By averaging all $56 \mathrm{~m} \times 56 \mathrm{~m}$ pixels within a watershed, the EPIC model introduces a degree of spatial variability into each environmental metric. This spatial variability was tested within the sensitivity analysis to define the degree to which spatial averaging impacted the results.

\section{Results}

NER was positive for all feedstock production portion scenarios, with the greatest average (46.0 MJ output $\mathrm{MJ}$ input ${ }^{-1}$ ) and individual watershed (51.5 $\mathrm{MJ}$ output $\mathrm{MJ}$ input ${ }^{-1}$ ) result occurring in the Miscanthus/lower N scenario and the least average (5.1 MJ output $\mathrm{MJ}$ input ${ }^{-1}$ ) and individual watershed (4.4 $\mathrm{MJ}$ output $\mathrm{MJ}$ input ${ }^{-1}$ ) result occurring in the corn stover/ higher $\mathrm{N}$ scenario (Table 3). NER was generally greatest for Miscanthus, followed by switchgrass, then corn stover, though approximately half of the individual watersheds exhibited greater NER under switchgrass/lower $\mathrm{N}$ conditions than under Miscanthus/higher N conditions.

Considering the average for GWP, AP, and EP, the perennial grasses outperformed corn stover in all cases. The corn stover averages for AP and EP were significantly greater than the average for the grasses, and the GWP averages for corn stover were slightly positive, indicating net annual $\mathrm{CO}_{2} \mathrm{eq}$ emissions. GWP averages for switchgrass and Miscanthus were negative, indicating net sequestration, with the greatest average sequestration (lowest average GWP) occurring in the switchgrass/lower $\mathrm{N}$ scenario $\left(-1.18 \mathrm{~kg} \mathrm{CO}_{2} \mathrm{eq} \mathrm{kg}^{-1}\right)$. Average AP results were slightly better for Miscanthus than switchgrass, and average EP results for Miscanthus were slightly negative, indicating a net beneficial effect regarding eutrophication, whereas average EP results for switchgrass were slightly positive.

The lower $\mathrm{N}$ scenarios generally produced slightly better results for all impact categories than higher $\mathrm{N}$ scenarios (Fig. 2). In the corn stover and Miscanthus scenarios, watersheds with lower $\mathrm{N}$ had more favorable GWP, AP, and EP; lower N resulted in more favorable GWP, AP, and $\mathrm{EP}$ for most watersheds in the switchgrass scenarios as well. NER was more favorable in lower $\mathrm{N}$ scenarios for all watersheds and all crops, demonstrating that the embodied energy in the additional nitrogen fertilizer can outweigh the energy resulting from increased yields.

Spatial variability across watersheds was not very substantial to modeled environmental impacts, with some exception. The highest degree of spatial variability was evident for the EP metric, especially for switchgrass, where EP watershed values ranged from -3.45 to $4.17 \mathrm{~kg} \mathrm{PO}_{4} \mathrm{eq} \mathrm{ha}^{-1}$ for the higher $\mathrm{N}$ scenario. Variability across watersheds for the other impact categories was mostly negligible. Looking at differences among feedstocks, the grasses outperformed corn stover in each metric on a per-hectare basis, with Miscanthus results exceeding those of switchgrass with the exception of AP. It should be noted that results for the feedstock production scenarios for corn stover do not include allocation or sub-division because the boundary of the feedstock production portion of the system is the farm gate and not the point of biomass use.

The final ethanol product with the greatest NER was the ethanol produced in the corn stover (sub-division)/lower N/DA scenario (9.00 MJ output MJ input ${ }^{-1}$ ), whereas the ethanol with the least final NER resulted from the Miscanthus/higher N/AFEX scenario (4.96 MJ output MJ input $^{-1}$ ) (Table 4). The least NER scenario produced the greatest quantity of ethanol but also required the greatest resource input to produce that ethanol, whereas the greatest NER scenario produced only about $13 \%$ of the ethanol produced in the least NER scenario, but resource input was also substantially less, approximately $7 \%$, of that required for the least NER scenario.

All lower nitrogen input scenarios had greater NER than their corresponding higher nitrogen input scenarios (Fig. 3). Similarly, scenarios that used DA pretreatment generally had greater NER results than the scenarios that used AFEX pretreatment, except for the corn stover scenarios that used sub-division and AFEX pretreatment; these two scenarios had greater than NER than the two corn stover (mass allocation)/DA scenarios. Comparing across feedstocks, the DA-pretreated corn stover (subdivision) produced greatest NER, followed by Miscanthus and switchgrass, with corn stover (mass allocation) further behind; for AFEX pretreatment, again, corn stover (sub-division) produced greatest NER, but followed by switchgrass, then corn stover (mass allocation), with Miscanthus at the bottom.

As with NER, lower $\mathrm{N}$ scenarios performed better regarding GWP, AP, and EP than the corresponding higher $\mathrm{N}$ scenarios, though results across feedstocks and pretreatment methods did not demonstrate such a uniform pattern. Specifically concerning GWP, feedstock selection 
Table 3 Impact category results per feedstock production scenario for average watershed value, minimum value, maximum value, and coefficients of variance (a. net energy ratio, MJ output $\mathrm{MJ}$ input $^{-1}$; b. global warming potential, $\mathrm{kg} \mathrm{CO}_{2} \mathrm{eq} \mathrm{kg}^{-1}$; c. acidification potential, $\mathrm{g} \mathrm{SO}_{2} \mathrm{eq}$ $\mathrm{kg}^{-1}$; d. eutrophication potential, $\mathrm{g} \mathrm{PO}_{4} \mathrm{eq} \mathrm{kg}^{-1}$ )

\begin{tabular}{|c|c|c|c|c|c|}
\hline \multicolumn{2}{|l|}{ Production scenario } & \multirow[t]{2}{*}{ Average } & \multirow[t]{2}{*}{ Minimum } & \multirow[t]{2}{*}{ Maximum } & \multirow[t]{2}{*}{$\operatorname{COV}(\%)$} \\
\hline \multirow{4}{*}{$\begin{array}{l}\text { a. Net energy ratio } \\
\text { Lower nitrogen input }\end{array}$} & & & & & \\
\hline & Corn stover & 5.7 & 4.8 & 6.4 & 7.6 \\
\hline & Switchgrass & 33.8 & 30.6 & 36.2 & 4.2 \\
\hline & Miscanthus & 46.0 & 39.3 & 51.5 & 5.8 \\
\hline \multirow[t]{3}{*}{ Higher nitrogen input } & Corn stover & 5.1 & 4.4 & 5.8 & 7.5 \\
\hline & Switchgrass & 30.2 & 27.2 & 33.1 & 5.7 \\
\hline & Miscanthus & 40.3 & 34.1 & 45.6 & 6.5 \\
\hline \multicolumn{6}{|c|}{ b. Global warming potential } \\
\hline \multirow[t]{3}{*}{ Lower nitrogen input } & Corn stover & 0.20 & 0.13 & 0.40 & 25 \\
\hline & Switchgrass & -1.18 & -1.36 & -1.10 & -3.9 \\
\hline & Miscanthus & -0.85 & -0.96 & -0.74 & -5.8 \\
\hline \multirow[t]{3}{*}{ Higher nitrogen input } & Corn stover & 0.27 & 0.19 & 0.63 & 36 \\
\hline & Switchgrass & -1.06 & -1.22 & -1.00 & -3.3 \\
\hline & Miscanthus & -0.79 & -0.88 & -0.71 & -4.8 \\
\hline \multicolumn{6}{|l|}{ c. Acidification potential } \\
\hline \multirow[t]{3}{*}{ Lower nitrogen input } & Corn stover & 1.54 & 1.37 & 1.80 & 7.7 \\
\hline & Switchgrass & 0.25 & 0.23 & 0.28 & 4.2 \\
\hline & Miscanthus & 0.20 & 0.18 & 0.23 & 6.0 \\
\hline \multirow[t]{3}{*}{ Higher nitrogen input } & Corn stover & 1.70 & 1.50 & 1.99 & 7.8 \\
\hline & Switchgrass & 0.28 & 0.25 & 0.31 & 5.7 \\
\hline & Miscanthus & 0.22 & 0.20 & 0.26 & 6.6 \\
\hline \multicolumn{6}{|c|}{ d. Eutrophication potential } \\
\hline \multirow[t]{3}{*}{ Lower nitrogen input } & Corn stover & 1.12 & 0.89 & 1.92 & 20 \\
\hline & Switchgrass & 0.01 & -0.27 & 0.24 & 1352 \\
\hline & Miscanthus & -0.16 & -0.27 & -0.07 & -35 \\
\hline \multirow[t]{3}{*}{ Higher nitrogen input } & Corn stover & 1.55 & 1.07 & 2.31 & 16 \\
\hline & Switchgrass & 0.07 & -0.26 & 0.37 & 259 \\
\hline & Miscanthus & -0.02 & -0.21 & 0.17 & -507 \\
\hline
\end{tabular}

appeared to be the most determinant factor when ranking scenarios: switchgrass scenarios had the best GWP outcomes, followed by Miscanthus scenarios, then corn stover/AFEX scenarios and corn stover/DA scenarios (Fig. 4). Relative to the entire range of GWP results, there was not much variation between same feedstock scenarios, and this includes all eight corn stover scenarios which performed notably worse than the perennials despite the different co-product treatments.

Feedstock was the most determinant regarding EP outcomes as well, though there was more overlap between feedstocks when measured using this metric: Miscanthus generally performed best, corn stover (sub-division) and switchgrass closely followed, and corn stover (mass allocation) performed decidedly worse (Fig. 5). For both GWP and EP, impacts from pretreatment contributed relatively little to overall impacts and did not vary widely between scenarios. However, when regarding AP, DA pretreatment impacts were greater than impacts from AFEX, which was demonstrated through the more favorable AP outcomes for AFEX scenarios (Fig. 6). Again, with exception for the corn stover (sub-division) scenarios, all AFEX scenarios had better AP results than the DA scenarios, and corn stover (sub-division) performed best, followed by the perennials, then corn stover (mass allocation).

Looking more closely at effects from the biomass pretreatment, the primary factor causing the difference between NER results in the DA and AFEX scenarios was the use of ammonia, which carries significant upstream impacts. Ammonia gas is used to raise the $\mathrm{pH}$ of hydrolysate slurry in DA pretreatment, but the quantity required is much less than that used in AFEX pretreatment; the ammonia in DA represented slightly more than $50 \%$ of the pretreatment contribution to NER, whereas the ammonia in AFEX represented 88-97\%. Ammonia is recycled in the AFEX process but not all of it is recoverable, furthering the disparity in NER between the two pretreatment methods. This difference in ammonia usage led also to improved GWP and EP outcomes in DA scenarios over AFEX scenarios, though pretreatment accounted for a small contribution to total GWP and EP, with less than $11 \%$ of the positive contribution to both metrics coming from this 


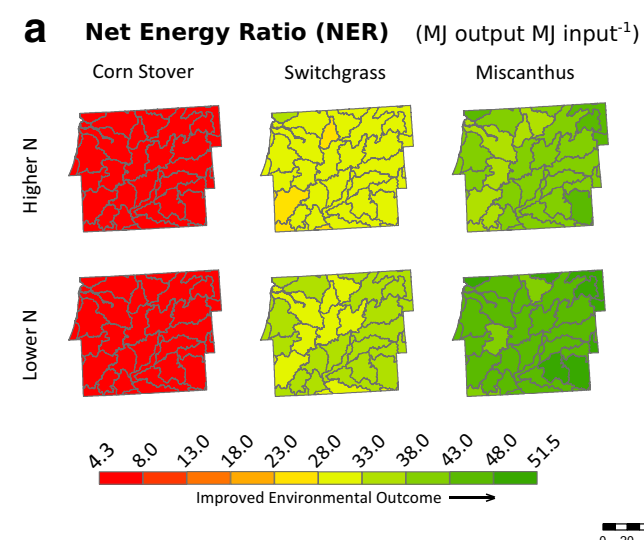

b Global Warming Potential (GWP) $\left(\mathrm{kg} \mathrm{CO}_{2}\right.$ eq ha-1 $)$
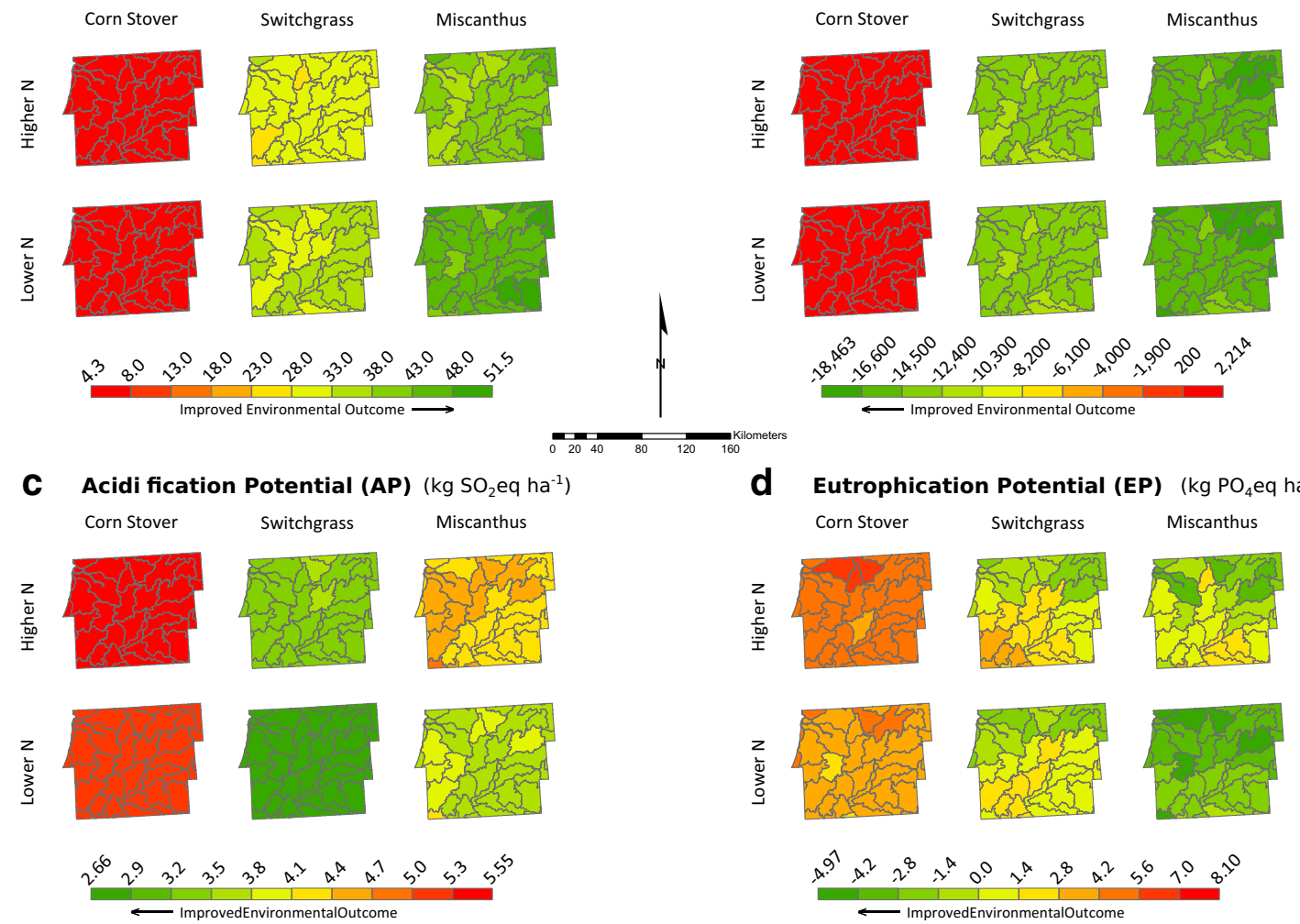

d Eutrophication Potential (EP) $\left(\mathrm{kg} \mathrm{PO}_{4} \mathrm{eq} \mathrm{ha}^{-1}\right)$

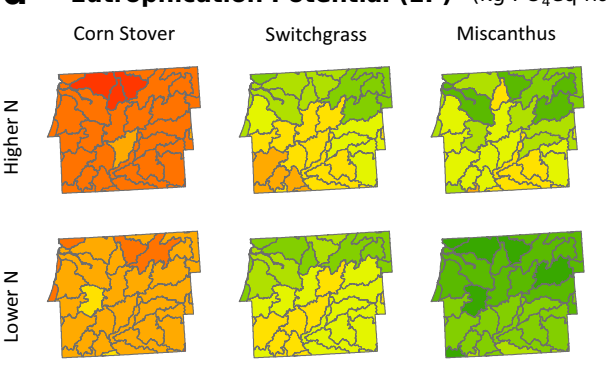

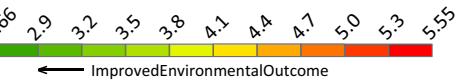

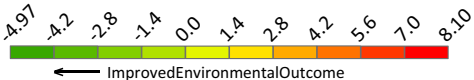

Fig. 2 Impact category results per feedstock production scenario for each watershed

Table 4 Ethanol energy output and life cycle impact category results for each scenario, aggregated to the RIMA scale (energy of denatured ethanol produced, MJ; net energy ratio, MJ output MJ input ${ }^{-1}$; global

\begin{tabular}{|c|c|c|c|c|c|c|c|}
\hline Scenario & & & $\begin{array}{l}\text { Energy of denatured } \\
\text { ethanol produced }\end{array}$ & $\begin{array}{l}\text { Net energy } \\
\text { ratio }\end{array}$ & $\begin{array}{l}\text { Global } \\
\text { warming } \\
\text { potential }\end{array}$ & $\begin{array}{l}\text { Acidification } \\
\text { potential }\end{array}$ & $\begin{array}{l}\text { Eutrophication } \\
\text { potential }\end{array}$ \\
\hline \multirow{4}{*}{$\begin{array}{l}\text { Corn stover } \\
\text { (mass } \\
\text { allocation) }\end{array}$} & \multirow[t]{2}{*}{ Higher N } & AFEX & $4.15 \mathrm{E}+10$ & 5.18 & 0.053 & 0.050 & 0.035 \\
\hline & & DA & $3.60 \mathrm{E}+10$ & 6.23 & 0.059 & 0.067 & 0.037 \\
\hline & \multirow[t]{2}{*}{ Lower N } & AFEX & $4.13 \mathrm{E}+10$ & 5.30 & 0.052 & 0.048 & 0.029 \\
\hline & & DA & $3.58 \mathrm{E}+10$ & 6.43 & 0.058 & 0.065 & 0.031 \\
\hline \multirow{4}{*}{$\begin{array}{l}\text { Corn stover } \\
\quad \text { (sub-division) }\end{array}$} & \multirow[t]{2}{*}{ Higher N } & AFEX & $4.15 \mathrm{E}+10$ & 6.65 & 0.050 & 0.028 & 0.016 \\
\hline & & DA & $3.60 \mathrm{E}+10$ & 8.97 & 0.055 & 0.042 & 0.015 \\
\hline & \multirow[t]{2}{*}{ Lower N } & AFEX & $4.13 \mathrm{E}+10$ & 6.66 & 0.050 & 0.028 & 0.016 \\
\hline & & DA & $3.58 \mathrm{E}+10$ & 9.00 & 0.055 & 0.042 & 0.015 \\
\hline \multirow[t]{4}{*}{ Switchgrass } & \multirow[t]{2}{*}{ Higher $N$} & AFEX & $1.63 \mathrm{E}+11$ & 5.45 & 0.016 & 0.037 & 0.017 \\
\hline & & DA & $1.41 \mathrm{E}+11$ & 7.41 & 0.013 & 0.052 & 0.017 \\
\hline & \multirow[t]{2}{*}{ Lower N } & AFEX & $1.42 \mathrm{E}+11$ & 5.52 & 0.011 & 0.036 & 0.016 \\
\hline & & $\mathrm{DA}$ & $1.22 \mathrm{E}+11$ & 7.55 & 0.008 & 0.051 & 0.015 \\
\hline \multirow[t]{4}{*}{ Miscanthus } & \multirow[t]{2}{*}{ Higher N } & AFEX & $2.66 \mathrm{E}+11$ & 4.96 & 0.026 & 0.038 & 0.015 \\
\hline & & DA & $2.30 \mathrm{E}+11$ & 7.47 & 0.025 & 0.052 & 0.012 \\
\hline & \multirow[t]{2}{*}{ Lower N } & AFEX & $2.49 \mathrm{E}+11$ & 5.01 & 0.024 & 0.037 & 0.010 \\
\hline & & DA & $2.15 \mathrm{E}+11$ & 7.60 & 0.023 & 0.051 & 0.007 \\
\hline
\end{tabular}

warming potential, $\mathrm{kg} \mathrm{CO}_{2} \mathrm{eq} \mathrm{MJ}^{-1}$; acidification potential, $\mathrm{g} \mathrm{SO}_{2} \mathrm{eq}$ $\mathrm{MJ}^{-1}$; eutrophication potential, $\mathrm{g} \mathrm{PO}_{4} \mathrm{eq}^{\mathrm{MJ}}{ }^{-1}$ ) 


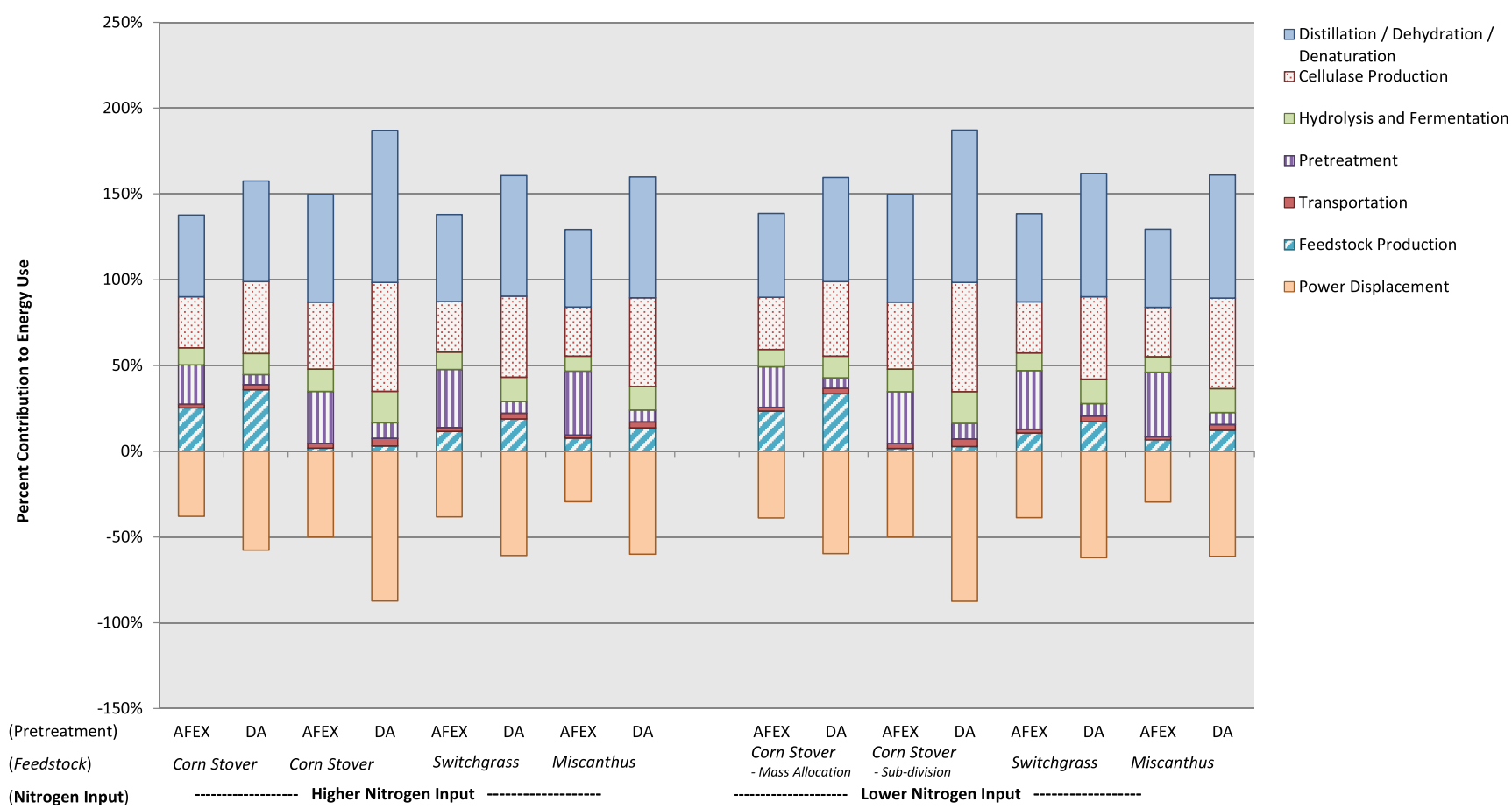

Fig. 3 Percent contribution to energy use for each scenario

process. With regard to acidification potential, over $99 \%$ of $\mathrm{SO}_{2}$ eq emissions were comprised of sulfur dioxide $\left(\mathrm{SO}_{2}\right)$, nitrogen oxides (NOx), and ammonia $\left(\mathrm{NH}_{3}\right)$; $\mathrm{NOx}$ and $\mathrm{NH}_{3}$ emissions were comparable between AFEX and DA pretreatment, though $\mathrm{SO}_{2}$ emissions were approximately $30 \%$ higher for DA than AFEX, contributing to improved outcomes in AFEX scenarios over DA scenarios.

The feedstock production portion was the source of the highest variability between scenarios. Contributions to net impacts from pretreatment and power displacement also varied

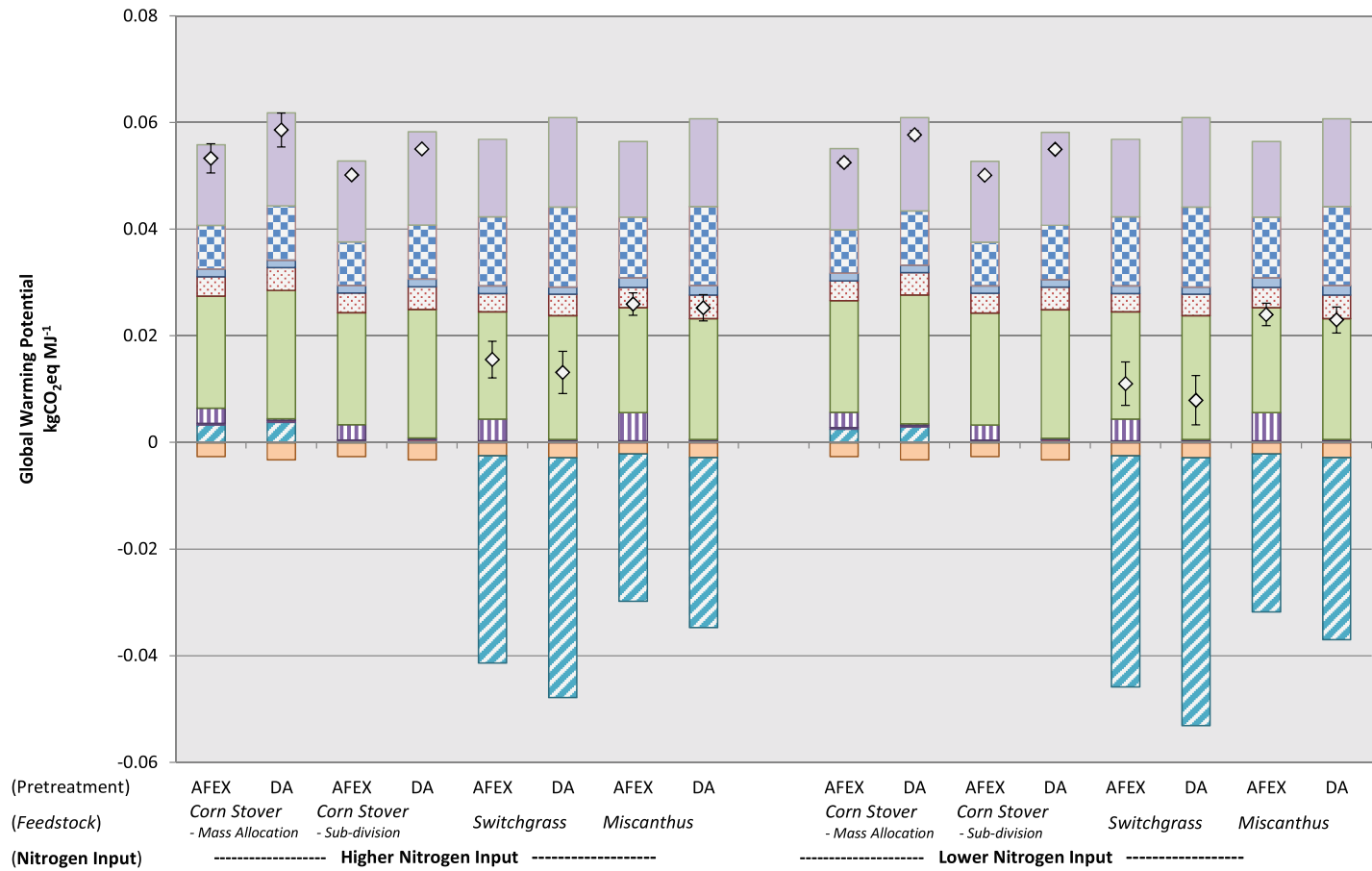

Wastewater Treatmen

Lignin Combustion

$\square$ Distillation / Dehydration / Denaturation Cellulase Production

$\square$ Hydrolysis and Fermentation

๓) Pretreatment

Transportation

$\square$ Feedstock Production

$\square$ Power Displacement

$\diamond$ Net Global Warming Potential

Fig. 4 Global warming potential $\left(\mathrm{kg} \mathrm{CO}_{2}\right.$ eq $\left.\mathrm{MJ}^{-1}\right)$ with contributions from each ethanol production process. Error bars demonstrate the range in net GWP due to spatial variability in feedstock yield 


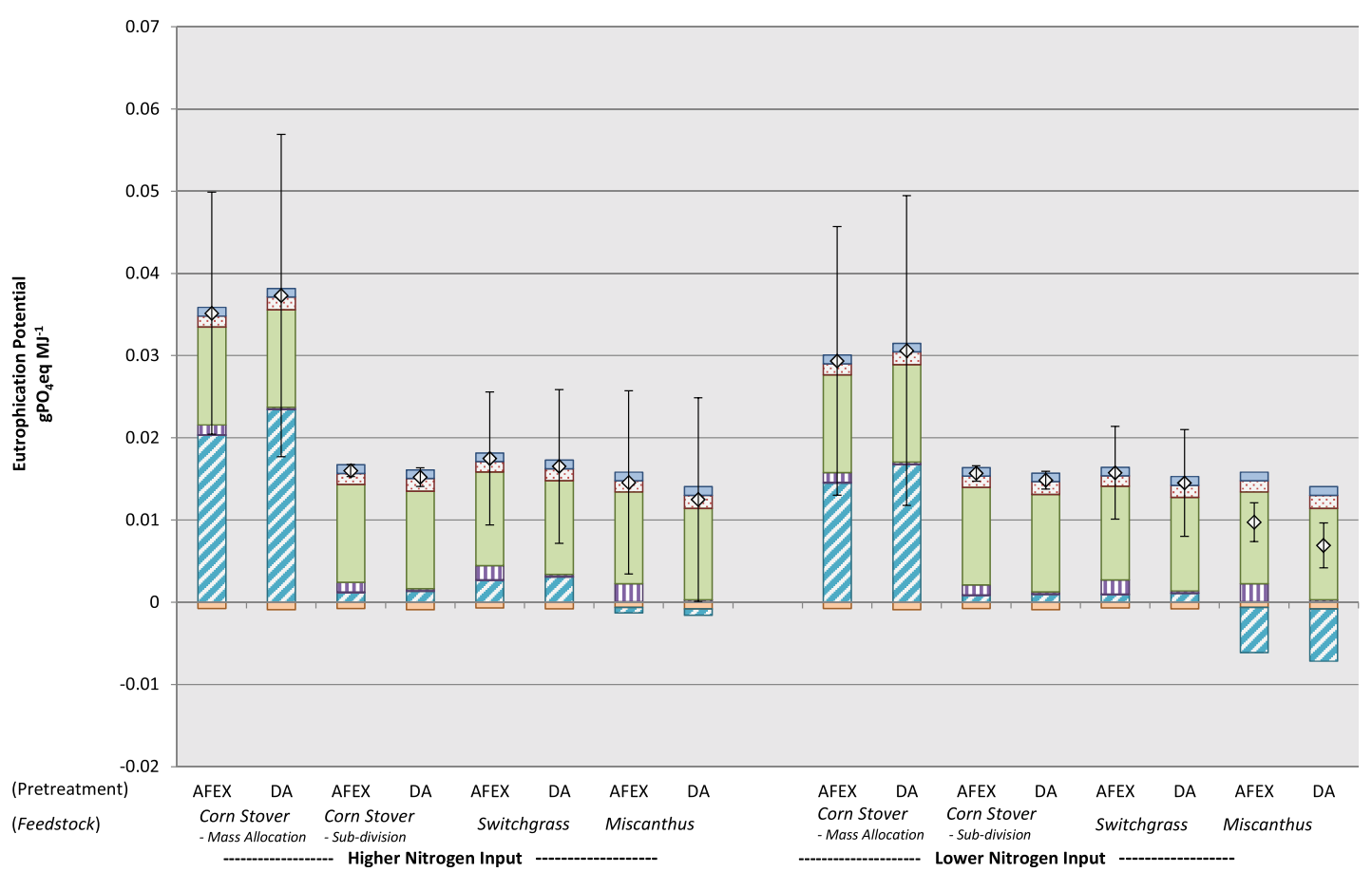

$\square$ Distillation / Dehydration /

Denaturation

๑ Cellulase Production

$\square$ Hydrolysis and Fermentation

口 Pretreatment

$\square$ Transportation

- Feedstock Production

$\square$ Power Displacement

$\diamond$ Net Eutrophication Potential

Fig. 5 Eutrophication potential $\left(\mathrm{g} \mathrm{PO}_{4} \mathrm{eq} \mathrm{MJ}^{-1}\right.$ ) with contributions from each ethanol production process. Error bars demonstrate the range in net EP due to spatial variability in feedstock yield

across scenarios, though generally to a lesser degree than feedstock production, and other contributions were relatively uniform and less dependent on scenario-specific factors. GWP feedstock production results were a positive component for corn stover and negative for grasses, thereby helping to reduce net GWP for the grasses, and for each metric, applying the sub-division co-product treatment method to corn stover drastically reduced the impacts from feedstock production compared to scenarios that used mass allocation instead. As would be expected, the difference in life cycle results between higher

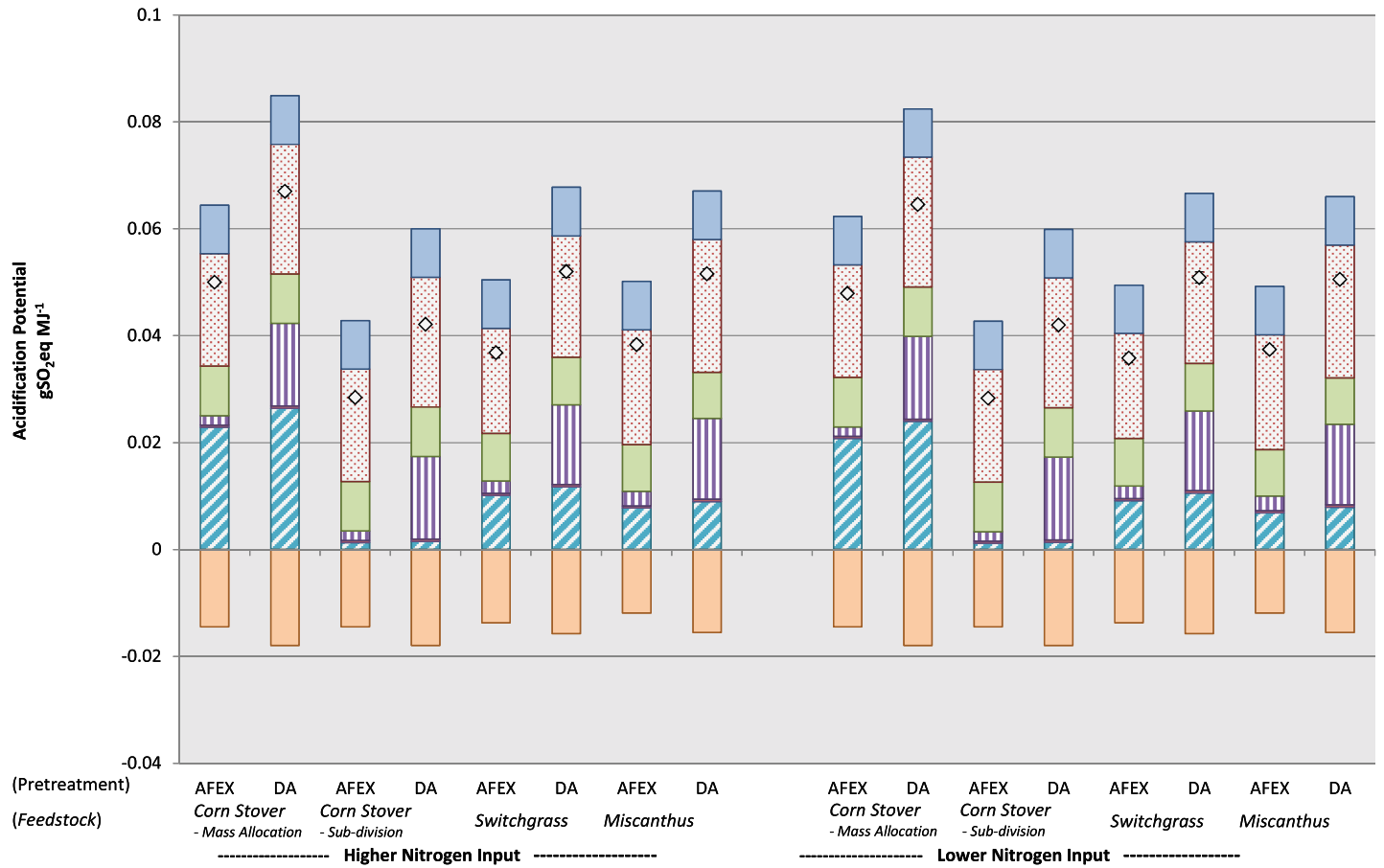

$\square$ Distillation / Dehydration / Denaturation $\checkmark$ Cellulase Production $\square$ Hydrolysis and Fermentation ๓) Pretreatment - Transportation $\square$ Feedstock Production $\square$ Power Displacement $\diamond$ Net Acidification Potentia

Fig. 6 Acidification potential $\left(\mathrm{g} \mathrm{SO}_{2} \mathrm{eq} \mathrm{MJ}^{-1}\right)$ with contributions from each ethanol production process. Error bars demonstrate the range in net AP due to spatial variability in feedstock yield 
$\mathrm{N}$ and lower $\mathrm{N}$ scenarios was muted after additional life cycle processes were included, although lower $\mathrm{N}$ produced better results for EP, particularly in the switchgrass scenarios.

\section{Discussion}

Spatial variability between watersheds within each of the six feedstock production phase scenarios was generally low (Fig. 2). Coefficients of variation, reported in Table 3, were mostly under $10 \%$, except for the global warming potential of the corn stover scenarios and the eutrophication potential of each scenario. Variation for GWP of corn stover remained relatively low. Eutrophication potential varied more at the production level since that impact was driven by runoff of nutrient fertilizers, which was governed by site-specific mechanisms. The geographical area considered spans nine contiguous counties in Southwestern Michigan where environmental conditions should be quite similar, so differences in impacts between watersheds under the same production regimes will not be as pronounced as with watersheds with more contrasting conditions. Another reason for the low spatial variability was that fertilizer input rates were held constant for each feedstock in each watershed, when in reality, producers would apply fertilizers based on field conditions which could lead to greater variability across all four impact categories. However, given the construction of this model, the insight prevails that environmental impact variability among feedstocks was much greater than across watersheds.

Overall, switchgrass and Miscanthus production resulted in more favorable outcomes than corn stover production. The grasses had higher NER than corn stover and had significantly lower GWP and AP. Corn stover generally had higher EP than switchgrass and Miscanthus as well, though in one watershed, EP was lower for corn stover than for switchgrass (Fig. 2). Overall, switchgrass and Miscanthus production resulted in more favorable outcomes than corn stover production; the grasses had higher NER than corn stover and significantly lower GWP and AP. Corn stover generally had higher EP than the perennials as well, though in one watershed, EP was lower for corn stover than for switchgrass on a per area basis (Fig. 2). Looking beyond the farm gate to the wider cellulosic ethanol production system, the two co-product treatment methods applied to corn stover made that feedstock much more competitive over the CE production life cycle with switchgrass and Miscanthus, particularly where the method of sub-division was applied. Based on the metrics of NER, AP, and EP, corn stover (sub-division) scenarios had more favorable outcomes than the perennial scenarios due to the reduction of feedstock production impacts to $2 \%$ of total corn production impacts. The recommendation of the ISO regarding co-product treatment is to use the sub-division when possible, though this treatment may not best represent future scenarios such as those in this study in which large amounts of stover are removed for cellulosic ethanol since the residue is no longer a marginal byproduct [33]. Energy allocation uses approximately the same ratio as mass, while economic allocation generally attributes much more burden to corn grain [34]. However, energetic comparison between stover and grain is unrealistic due to their separate purposes, and economic comparison introduces a slight degree of variability due to fluctuating market demand and pricing [23]. Though mass allocation conservatively influences the results of corn stover production, it provides a practical treatment option and offers a contrast with the subdivision treatment method.

Notably, all scenarios represent changes from a baseline scenario, mainly because corn stover scenarios were similar to the baseline scenario except for $50 \%$ stover removal. This stover removal accounts for the direct and upstream impacts in the corn stover scenarios. For example, GWP was slightly positive for corn stover scenario watersheds, indicating slightly positive net $\mathrm{CO}_{2}$ eq emissions. These net emissions arose from the removal of carbon in the stover harvested from the field. By contrast, the switchgrass and Miscanthus scenarios were quite dissimilar to the baseline scenario; as a result, there were more factors influencing environmental impacts from the grasses, and those impacts followed similar trends across feedstocks.

Feedstock yield has a critical role in the favorability of scenario outcomes, an observation demonstrated in this study and noted by others [4]. Maximizing yield by applying a greater quantity of nitrogen translates to more energy produced and more economic return for the producer, but in the six production scenarios, NER was more favorable under lower $\mathrm{N}$ conditions than under higher $\mathrm{N}$ conditions for each feedstock in every watershed, and the additional nitrogen increased GWP as well as direct $\mathrm{N}_{2} \mathrm{O}$ emissions in the field. So while higher $\mathrm{N}$ increased yields, the marginal increase over lower $\mathrm{N}$ yields was not very significant, and the upstream energy required to deliver the additional nitrogen was greater than the additional energy harvested in the feedstock. An argument could be made in favor of higher $\mathrm{N}$, however, if demand for feedstock at the biorefinery exceeded the yield potential of the RIMA. In that case, NER could decrease and environmental impacts may increase in a lower $\mathrm{N}$ scenario due to the energy and emissions costs of transporting feedstock over further distances or due to harvesting biomass from more environmentally sensitive or less productive land. Closer analysis of the tradeoff between nitrogen impacts and yield targets would be required in such a scenario.

Differences between DA and AFEX pretreatment led to DA scenarios having better NER, GWP, and EP outcomes than AFEX scenarios. The increased quantity of ammonia gas in AFEX was a significant difference, but steam requirements in pretreatment were also significantly greater for AFEX than DA. Comparing within the AFEX pretreatment 
scenarios, Miscanthus in particular requires high severity pretreatment which results in increased ammonia use [25]. Miscanthus/AFEX scenarios rank at the bottom for NER because of this high severity requirement, as well as other pretreatment input parameters.

Though iLUC impacts were excluded from this study, it is worth speculating how their inclusion might affect the results in a general sense. In the corn stover scenarios, iLUC would be expected to be negligible, since the shift from the baseline scenario involves only collection of stover with the primary commodities (corn grain and soybeans) continuing to be produced. However, iLUC impacts could be substantial for the switchgrass and Miscanthus scenarios: Searchinger et al. [35] estimated that replacing corn production with switchgrass production may increase GHG emissions by $50 \%$ over 30 years due to land use change effects. Reported iLUC values in LCA literature for cellulosic crops are lacking, though the GREET model, which primarily uses national-scale data for the USA, uses default iLUC values of $-0.0005 \mathrm{~kg}$ $\mathrm{CO}_{2}$ eq $\mathrm{MJ}^{-1}$ for corn stover-derived ethanol, $0.0071 \mathrm{~kg}$ $\mathrm{CO}_{2} \mathrm{eq} \mathrm{MJ}^{-1}$ for switchgrass-derived ethanol, and $0.0022 \mathrm{~kg} \mathrm{CO}_{2} \mathrm{eq} \mathrm{MJ}^{-1}$ for Miscanthus-derived ethanol [36]. Including such values would very slightly reduce net GHG emissions for the corn stover scenarios and slightly reduce net GHG sequestration for the switchgrass and Miscanthus scenarios.

Current LCA literature discusses environmental impacts due to CE production from corn stover, switchgrass, and Miscanthus, though results are difficult to compare due to differences in data, assumptions, and site-specific conditions $[1,37]$. Analyses similar to the present study often include incongruent system boundaries [38, 39], geographical scope [40], or some combination of these and other factors [41-43]. Of the analyses most comparable to this study, the prevailing metric for evaluating environmental impact is global warming potential. Murphy and Kendall [44] evaluated over 30 production scenarios for $\mathrm{CE}$ derived from corn stover and switchgrass and estimated life cycle GWP values of 0.025 and $0.031 \mathrm{~kg} \mathrm{CO}_{2} \mathrm{eq} \mathrm{MJ}^{-1}$ for corn stover- and switchgrassderived $\mathrm{CE}$, respectively, for the scenarios that included an electricity co-product. The authors relied on average feedstock yield data and note that their results may differ from evaluations that account for spatially explicit conditions. Scown et al. [45] developed six scenarios based on county-level analysis of Miscanthus production, each designed to meet the Energy Independence and Security Act of 2007 (EISA) cellulosic ethanol annual production requirement of 39.7 billion liters by 2020 [46] with Miscanthus-derived ethanol. In the scenario most similar to those considered in this study, they estimated a net sequestration of $0.003-0.027 \mathrm{~kg} \mathrm{CO}_{2}$ eq $\mathrm{MJ}^{-1}$ over two to five decades depending on the form of power generation that is displaced by the electricity co-product. Both analyses used a system boundary similar to that presented in this study but included neither estimations of NER nor other environmental impacts.

\section{Conclusions}

Life cycle analyses of agricultural products such as this study can provide more meaningful findings when they incorporate site-specific data, especially in identifying local impacts such as acidification and eutrophication. This study used the most local data available for each process in the cradle-to-refinery gate life cycle of CE pathways, though spatial variation was generally found to be subtle across the watersheds of the ninecounty area of the Michigan RIMA. Feedstock production scenario results varied more due to feedstock than location, with switchgrass and Miscanthus demonstrating better energy and environmental outcomes than corn stover in almost every case, primarily due to higher feedstock yields and lower resource input requirements.

Comparing $16 \mathrm{CE}$ production scenarios that varied by feedstock, nitrogen input, pretreatment method, and co-product treatment method demonstrated a number of trends, though none of the 16 emerged as the "optimal" scenario. A lower nitrogen input rate offered more favorable results based on the four impact category metrics, and DA pretreatment generally provided better results than AFEX pretreatment. Applying a co-product treatment method to the corn stover feedstock boosted its standing compared to switchgrass and Miscanthus, though these treatment methods are accounting choices that may not reflect the whole story. Even with a generous attribution of impacts to corn stover through subdividing items related to corn grain, that feedstock is, at best, competitive with perennial feedstocks. However, in a practical sense, corn has the advantages of being an established agricultural product with multiple end uses and a shorter investment horizon, advantages that perennials do not share. Recent studies have proposed a supply model featuring biomass processing depots to address logistical challenges within CE production [47-49]. It has also been proposed that such a model would improve energy and environmental outcomes for AFEX-treated CE pathways [25, 47]. It was clear from the present study that proper accounting of pretreatment process impacts was significant to life cycle results of $\mathrm{CE}$ production. Additional comparable studies of the life cycle of CE, especially that deriving from Miscanthus, would help to test the validity of the results presented here, and a standard system boundary for similar LCAs would improve wider comparisons of this type of research.

Spatially explicit CE research offers benefits beyond the academic arena. For the agricultural producer with interests in CE, this type of research might help identify a bioenergy feedstock with the potential for most yield and financial profit, 
as well as hazards and logistical barriers that could limit the favorability of a particular feedstock due to inherent geography, climate, or land capability. Studying a range of scenarios could also reduce uncertainty in long-term land management decision making, considering the life span of perennial grasses like switchgrass and Miscanthus. For the policymaker, results like those presented here can clarify environmental tradeoffs of different feedstocks with more local precision, reducing odds for unintended consequences from bioenergy production.

As discussed in the paper, indirect land use change implications were excluded from the scope of this study due to the complicated nature of quantifying them; undertaking a sitespecific analysis of iLUC impacts initiated within the 16 ethanol production scenarios would enhance their results. Though there is a difference in scope of data, the GREET model $[36,43]$ could offer a starting point for addressing iLUC emissions in future CE scenarios. Another strategy could be to limit the scope of analysis to marginal lands not in current production and which may accommodate perennial crops like switchgrass and Miscanthus and avoid both iLUC and LUC impacts induced by the displacement of food and feed crops [50]. Developing spatially explicit marginal lands scenarios for CE pathways would also further expand the breadth of understanding of impacts from the growing $\mathrm{CE}$ industry.

Acknowledgments This work was funded in part by the DOE Great Lakes Bioenergy Research Center (DOE BER Office of Science DEFC02-07ER64494) and DOE OBP Office of Energy Efficiency and Renewable Energy (DE-AC05-76RL01830). The authors also gratefully acknowledge the contributions and guidance of Dr. Paul Meier, Dr. Bryan Bals, and Dr. Bruce Dale.

Open Access This article is distributed under the terms of the Creative Commons Attribution 4.0 International License (http:// creativecommons.org/licenses/by/4.0/), which permits unrestricted use, distribution, and reproduction in any medium, provided you give appropriate credit to the original author(s) and the source, provide a link to the Creative Commons license, and indicate if changes were made.

\section{References}

1. Chum H, A. Faaij, J. Moreira, G. Berndes, P. Dhamija, H. Dong, B. Gabrielle, A. Goss Eng, W. Lucht, M. Mapako, O. Masera Cerutti, T. McIntyre, T. Minowa, K. Pingoud (2011) Bioenergy. In IPCC special report on renewable energy sources and climate change mitigation

2. Mosier N, Wyman C, Dale B, Elander R, Lee YY, Holtzapple M, Ladisch M (2005) Features of promising technologies for pretreatment of lignocellulosic biomass. Bioresour Technol 96(6):673-686. doi:10.1016/j.biortech.2004.06.025

3. Thompson DN, Campbell T, Bals B, Runge T, Teymouri F, Ovard LP (2013) Chemical preconversion: application of low-severity pretreatment chemistries for commoditization of lignocellulosic feedstock. Biofuels 4 (3):323-340. doi:10.4155/bfs.13.15

4. Cherubini F, Bird ND, Cowie A, Jungmeier G, Schlamadinger B, Woess-Gallasch S (2009) Energy- and greenhouse gas-based LCA of biofuel and bioenergy systems: key issues, ranges and recommendations. Resour Conserv Recycl 53(8):434 447. doi:10.1016/j. resconrec.2009.03.013

5. Sinistore JC, Reinemann DJ, Izaurralde RC, Cronin KR, Meier PJ, Runge TM, Zhang X (2015) Life cycle assessment of switchgrass cellulosic ethanol production in the Wisconsin and Michigan agricultural contexts. BioEnergy Res. doi:10.1007/s12155-015-9611-4

6. Potting J, Hauschild MZ (2006) Spatial differentiation in life cycle impact assessment - a decade of method development to increase the environmental realism of LCIA. Int J Life Cycle Assess 11:1113. doi:10.1065/lca2006.04.005

7. Mutel CL, Pfister S, Hellweg S (2012) GIS-based regionalized life cycle assessment: how big is small enough? Methodology and case study of electricity generation (vol 46, pg 1096, 2012). Environ Sci Technol 46(23):13028-13028. doi:10.1021/es304634t

8. Nansai K, Moriguchi Y, Suzuki N (2005) Site-dependent life-cycle analysis by the SAME approach: its concept, usefulness, and application to the calculation of embodied impact intensity by means of an input-output analysis. Environ Sci Technol 39(18):7318-7328. doi:10.1021/es047951n

9. ISO (2006) ISO 14040: environmental management-life cycle assessment-principles and framework. International Organization for Standardization, Geneva, Switzerland

10. ISO (2006) ISO 14044: environmental management-life cycle assessment, life cycle impact assessment. International Organization for Standardization, Geneva, Switzerland

11. PE (1992-2015) GaBi 5: software-system and databases for life cycle engineering. Copyright, TM. Stuttgart, Echterdingen

12. Spatari S, Bagley DM, MacLean HL (2010) Life cycle evaluation of emerging lignocellulosic ethanol conversion technologies. Bioresour Technol 101(2):654-667. doi:10.1016/j. biortech.2009.08.067

13. Zhang X, Izaurralde RC, Manowitz D, West TO, Post WM, Thomson AM, Bandaruw VP, Nichols J, Williams JR (2010) An integrative modeling framework to evaluate the productivity and sustainability of biofuel crop production systems. Glob Chang Biol Bioenergy 2 (5):258-277. doi:10.1111/j.1757-1707.2010.01046.x

14. He X, Izaurralde RC, Vanotti MB, Williams JR, Thomson AM (2006) Simulating long-term and residual effects of nitrogen fertilization on corn yields, soil carbon sequestration, and soil nitrogen dynamics. J Environ Qual 35(4):1608-1619. doi:10.2134 /jeq2005.0259

15. Izaurralde RC, Williams JR, Post WM, Thomson AM, McGill WB, Owens LB, Lal R (2007) Long-term modeling of soil C erosion and sequestration at the small watershed scale. Clim Chang 80(1-2):7390. doi:10.1007/s10584-006-9167-6

16. Izaurralde RC, McGill WB, Williams JR (2012) Development and application of the EPIC model for carbon cycle, greenhouse gas mitigation, and biofuel studies. managing agricultural greenhouse gases: coordinated agricultural research through gracenet to address our changing climate. 293-308. doi:10.1016/b978-0-12-3868978.00017-6

17. Wang X, Williams JR, Gassman PW, Baffaut C, Izaurralde RC, Jeong J, Kiniry JR (2012) EPIC and APEX: model use, calibration, and validation. Trans ASABE 55(4):1447-1462

18. Zhang XS, Izaurralde C, Arnold JG, Sammons NB, Manowitz DH, Thomson AM, Williams JR (2011) Comment on "Modeling Miscanthus in the Soil and Water Assessment Tool (SWAT) to simulate its water quality effects as a bioenergy crop“. Environ Sci Technol 45 (14):6211-6212. doi:10.1021/es201463x

19. Dohleman FG, Heaton EA, Arundale RA, Long SP (2012) Seasonal dynamics of above- and below-ground biomass and 
nitrogen partitioning in Miscanthus $\mathrm{x}$ giganteus and Panicum virgatum across three growing seasons. Glob Chang Biol Bioenergy 4 (5):534-544. doi:10.1111/j.1757-1707.2011.01153.x

20. Zhang XS, Izaurralde RC, Manowitz DH, Sahajpal R, West TO, Thomson AM, Xu M, Zhao K, LeDuc SD, Williams JR (2015) Regional scale cropland carbon budgets: evaluating a geospatial agricultural modeling system using inventory data. Environ Model Softw 63:199-216. doi:10.1016/j.envsoft.2014.10.005

21. Kaufman AS, Meier PJ, Sinistore JC, Reinemann DJ (2010) Applying life-cycle assessment to low carbon fuel standardshow allocation choices influence carbon intensity for renewable transportation fuels. Energ Policy 38(9):5229-5241. doi:10.1016 /j.enpol.2010.05.008

22. Whitman T, Yanni SF, Whalen JK (2011) Life cycle assessment of corn stover production for cellulosic ethanol in Quebec. Can J Soil Sci 91(6):997-1012. doi:10.4141/cjss2011-011

23. Murphy CW, Kendall A (2013) Life cycle inventory development for corn and stover production systems under different allocation methods. Biomass Bioenergy 58:67-75. doi:10.1016/j. biombioe.2013.08.008

24. Bals B Personal communication, 26 January 2011. Michigan State University

25. Bals B Personal communication, 25 September 2013. Michigan Biotechnology Institute

26. Laser M, Jin HM, Jayawardhana K, Lynd LR (2009) Coproduction of ethanol and power from switchgrass. Biofuels Bioprod Biorefin 3 (2):195-218. doi:10.1002/bbb.133

27. Humbird D, Davis R, Tao L, Kinchin C, Hsu D, Aden A, Schoen P, Lukas J, Olthof B, Worley M, Sexton D, Dudgeon D (2011) Process design and economics for biochemical conversion of lignocellulosic biomass to ethanol: dilute-acid pretreatment and enzymatic hydrolysis of corn stover. National Renewable Energy Laboratory, Golden, $\mathrm{CO}$

28. Meier PJ (2012) myPower Methodology Documentation

29. (2010) ANL Greenhouse gases, Regulated Emissions, and Energy use in Transportation Model, GREET Version 1.8C. Accessed Mar 2010

30. NREL (2008) U.S. Life-Cycle Inventory (LCI) database. National Renewable Energy Laboratory

31. Ecoinvent (2007) Ecoinvent data. v2.0. Ecoinvent Reports 1-25. Swiss Centre for Life Cycle Inventories. Dübendorf

32. Finkbeiner M (2014) Indirect land use change - help beyond the hype? Biomass Bioenergy 62:218-221. doi:10.1016/j. biombioe.2014.01.024

33. Gerbrandt K, Chu PL, Simmonds A, Mullins KA, MacLean HL, Griffins WM, Saville BA (2016) Life cycle assessment of lignocellulosic ethanol: a review of key factors and methods affecting calculated GHG emissions and energy use. Curr Opin Biotechnol 38: 63-70. doi:10.1016/j.copbio.2015.12.021

34. Luo L, van der Voet E, Huppes G, de Haes HAU (2009) Allocation issues in LCA methodology: a case study of corn stover-based fuel ethanol. Int J Life Cycle Assess 14(6):529-539. doi:10.1007 /s11367-009-0112-6

35. Searchinger T, Heimlich R, Houghton RA, Dong F, Elobeid A, Fabiosa J, Tokgoz S, Hayes D, Yu T-H (2008) Use of US croplands for biofuels increases greenhouse gases through emissions from land-use change. Science 319 (5867):1238-1240. doi:10.1126 /science.1151861
36. (2015) ANL Greenhouse gases, Regulated Emissions, and Energy use in Transportation Model, GREET version 2015. Accessed Jun 2016

37. Borrion AL, McManus MC, Hammond GP (2012) Environmental life cycle assessment of lignocellulosic conversion to ethanol: a review. Renew Sust Energ Rev 16 (7):4638-4650. doi:10.1016/j. rser.2012.04.016

38. Schmer MR, Vogel KP, Mitchell RB, Perrin RK (2008) Net energy of cellulosic ethanol from switchgrass. Proc Natl Acad Sci U S A 105(2):464-469. doi:10.1073/pnas.0704767105

39. Davis SC, Parton WJ, Del Grosso SJ, Keough C, Marx E, Adler PR, DeLucia EH (2012) Impact of second-generation biofuel agriculture on greenhouse-gas emissions in the corn-growing regions of the US. Front Ecol Environ 10(2):69-74. doi:10.1890/110003

40. Choudhary S, Liang S, Cai H, Keoleian GA, Miller SA, Kelly J, Xu M (2014) Reference and functional unit can change bioenergy pathway choices. Int J Life Cycle Assess 19(4):796-805. doi:10.1007 /s11367-013-0692-z

41. MacLean HL, Spatari S (2009) The contribution of enzymes and process chemicals to the life cycle of ethanol. Environ Res Lett 4(1). doi:10.1088/1748-9326/4/1/014001

42. Bai Y, Luo L, van der Voet E (2010) Life cycle assessment of switchgrass-derived ethanol as transport fuel. Int J Life Cycle Assess 15(5):468-477. doi:10.1007/s11367-010-0177-2

43. Wang M, Han J, Dunn JB, Cai H, Elgowainy A (2012) Well-towheels energy use and greenhouse gas emissions of ethanol from corn, sugarcane and cellulosic biomass for US use. Environ Res Lett 7(4):13. doi:10.1088/1748-9326/7/4/045905

44. Murphy CW, Kendall A (2015) Life cycle analysis of biochemical cellulosic ethanol under multiple scenarios. Glob Chang Biol Bioenergy 7 (5):1019-1033. doi:10.1111/gcbb.12204

45. Scown CD, Nazaroff WW, Mishra U, Strogen B, Lobscheid AB, Masanet E, Santero NJ, Horvath A, McKone TE (2012) Lifecycle greenhouse gas implications of US national scenarios for cellulosic ethanol production. Environ Res Lett 7(1). doi:10.1088/1748-9326 /7/1/014011

46. Energy Independence and Security Act of 2007 (2007). vol Pub. L. no. $110-140$

47. Eranki PL, Bals BD, Dale BE (2011) Advanced regional biomass processing depots: a key to the logistical challenges of the cellulosic biofuel industry. Biofuels Bioprod Biorefin 5 (6):621-630. doi:10.1002/bbb.318

48. Eranki PL, Manowitz DH, Bals BD, Izaurralde RC, Kim S, Dale BE (2013) The watershed-scale optimized and rearranged landscape design (WORLD) model and local biomass processing depots for sustainable biofuel production: integrated life cycle assessments. Biofuels Bioprod Biorefin 7 (5):537-550. doi:10.1002 /bbb.1426

49. Kim S, Dale BE (2015) Comparing alternative cellulosic biomass biorefining systems: centralized versus distributed processing systems. Biomass Bioenergy 74:135-147. doi:10.1016/j. biombioe.2015.01.018

50. Gelfand I, Sahajpal R, Zhang XS, Izaurralde RC, Gross KL, Robertson GP (2013) Sustainable bioenergy production from marginal lands in the US Midwest. Nature 493(7433):514-+. doi:10.1038/nature11811 